\title{
The Developmental Changes in Mitochondrial DNA Content per Cell in Human Cord Blood Leukocytes during Gestation
}

\author{
M. PEJZNOCHOVÁ, M. TESAŘOVÁ, T. HONZÍK, H. HANSÍKOVÁ, M. MAGNER, \\ J. ZEMAN
}

Department of Pediatrics and Center for Applied Genomics, Faculty of Medicine, Charles

University, Prague, Czech Republic

Received March 16, 2007

Accepted October 3, 2007

On-line November 30, 2007

\begin{abstract}
Summary
The mitochondrial DNA (mtDNA) amount in cells as the basis for mitochondrial energy generating system, which produces ATP, plays an important role in the fetal development and postnatal morbidity. Isolated human cord blood leukocytes (HCBL) contribute very little to the overall metabolic turnover, but they may serve as easily available marker cells for the study of the mtDNA amount changes in cord blood during fetal development. The aim of our study was to analyze the mtDNA amount in HCBL. HCBL were isolated from cord blood samples of 107 neonates born between the $25^{\text {th }}$ and $41^{\text {st }}$ week of gestation. The mtDNA amount was analyzed by the real-time PCR method. The significant negative correlations were found between the relative mtDNA amount in HCBL and gestational age $(r=-0.54, p<0.01)$ and birth weight $(r=-0.43, p<0.01)$, respectively. The results revealed that the mtDNA content per cell decreases in $\mathrm{HCBL}$ with progressing fetal development. This may be explained by gradual shift of the hematopoiesis from fetal liver to bone marrow during the second half of pregnancy presumably accompanied by decreasing cell volume of HCBL as it was shown similarly in red blood cells.
\end{abstract}

\section{Key words}

Mitochondrial DNA - Human cord blood leukocytes - Real-time PCR

\section{Corresponding author}

J. Zeman, Department of Pediatrics, Faculty of Medicine, Charles University, Ke Karlovu 2, 12000 Prague 2, Czech Republic. Fax: +420-224967099. E-mail: jzem@lf1.cuni.cz

\section{Introduction}

Human mitochondrial DNA (mtDNA) is a circular double-stranded molecule encoding for 13 proteins of oxidative phosphorylation system (OXPHOS), which is composed of four respiratory chain complexes and ATP synthase located in the inner mitochondrial membrane (Papa 1996). The other OXPHOS proteins are encoded by nuclear genes. About 2-10 mtDNA copies are presented in each of hundreds or thousands of mitochondria per cell. Postnatal switch of glycolytic to oxidative metabolism is of crucial importance for all mammalian neonates and it is essential for successful adaptation to extra-uterine life. The process of OXPHOS maturation during the development of the fetus is still not fully understood during the development of the fetus (Honzík et al. 2007). It is an essential query because all mammalian tissues and cells except erythrocytes fully depend on ATP produced by oxidative phosphorylation in mitochondria.

It is known that the amount of mitochondrial DNA (mtDNA) could play an important role in the fertilizability of human oocytes (Reynier et al. 2001) and in the development of very early human embryo (Steuerwald et al. 2000). These results are vindicated by animal studies focused on very early development (Vallejo et al. 1996, Tamassia et al. 2004, Alcolea et al. 2006, May-Panloup et al. 2005). On the other hand, only scarce data from sporadic studies performed on human and animal samples are available on mtDNA content in various cells and tissues during fetal development. It was shown that the amount of mtDNA increases with human 
Table 1. Gestational age and birth weight of 107 newborns whose cord blood was used in the study.

\begin{tabular}{ccccc}
\hline Subgroup & $\begin{array}{c}\text { Number } \\
\text { (n) }\end{array}$ & $\begin{array}{c}\text { Gestational age } \\
\text { (week) }\end{array}$ & $\begin{array}{c}\text { Birth weight } \\
\text { (gram) median (range) }\end{array}$ & $\begin{array}{c}\text { Gender (n) } \\
\text { male / female }\end{array}$ \\
\hline 1 & 3 & 25 & $799(660-980)$ & $1 / 2$ \\
2 & 4 & 28 & $1220(1070-1360)$ & $2 / 2$ \\
3 & 8 & 30 & $1663(1270-2500)$ & $4 / 4$ \\
4 & 4 & 32 & $1388(1150-1625)$ & $0 / 4$ \\
5 & 11 & 33 & $2068(1760-2545)$ & $5 / 6$ \\
6 & 7 & 34 & $2485(1690-3580)$ & $6 / 2$ \\
7 & 13 & 35 & $2215(1740-2640)$ & $10 / 3$ \\
8 & 6 & 36 & $2543(1570-3000)$ & $2 / 4$ \\
9 & 8 & 37 & $2957(2650-3460)$ & $5 / 3$ \\
10 & 8 & 38 & $3314(2710-5060)$ & $1 / 6$ \\
11 & 13 & 39 & $3540(3090-3900)$ & $5 / 8$ \\
12 & 11 & 40 & $3286(2790-3830)$ & $2 / 9$ \\
13 & 11 & 41 & $3751(3350-4000)$ & $4 / 7$ \\
\hline
\end{tabular}

fetal development in heart, liver, kidney or brain (Heerdt and Augenlicht 1990, Garcia et al. 2000), but not in bone marrow, spleen or stomach (Heerdt and Augenlicht 1990). No detailed data are available on the changes of mtDNA amount in human cord blood leukocytes (HCBL) during fetal development.

The complete understanding of the regulation of mitochondrial function and biogenesis in early human development is essential mainly for diagnosis of the primary genetically encoded disorders of energy provision. These disorders are difficult to be distinguished from the secondary mitochondrial disturbances, especially in critically ill premature neonates (Honzik et al. 2007). The easy availability of HCBL without an invasive procedure could lead to its more frequent use in molecular or biochemical studies focused on human fetal development. Isolated HCBL contribute very little to the overall metabolic turnover, but they may serve as easily available marker cells for the study of the mtDNA amount changes in cord blood during gestation.

The general aim of this study was to analyze the changes in the mtDNA content in HCBL during human fetal development. In addition, it was the first step in verification of the hypothesis about the increase of mtDNA amount in HCBL as it was described in the some developing tissues (Heerdt and Augenlicht 1990, Garcia et al. 2000). It was essential to develop a sensitive and effective assay for quantification the mtDNA amount in HCBL. We decided to use the real-time PCR method. In spite of the fact that several methods have been already developed using real-time PCR to monitor mtDNA amount in human or animal cells (Andreasson et al. 2002, Von Wurmb-Schwark et al. 2002, Pogozelski et al. 2003, Alonso et al. 2004, Nicklas et al. 2004, Timmermans et al. 2006), it is necessary to optimize a real-time PCR method for specific experimental aim (Brisson et al. 2004).

\section{Materials and Methods}

\section{Isolation of genomic DNA from $H C B L$}

Cord blood samples were collected from the placental part of the umbilical cord immediately after the delivery of the child $(n=107)$. Neonates were born at the gestational age between 25-41 weeks of gestation and all pregnancies were uneventful till birth (Table 1). Family history in all neonates was without any symptoms of mitochondrial disorders. The group of 107 cord blood samples was divided into 13 subgroups according to the week of gestation.

All cord blood samples were taken into tubes with EDTA (BD Vacutainer $\left.{ }^{\circledR}\right)$. DNA was extracted from HCBL by the isolation according to Kendall et al. (1991) with some modifications. For selective lysis of erythrocytes was used modified lysis buffer $(150 \mathrm{mM}$

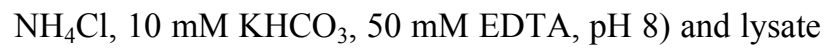
was digested by proteinase $\mathrm{K}$ in SDS and EDTA (10\% SDS, 0.5 M EDTA). The extracted genomic DNA was diluted in TE buffer and stored at $4{ }^{\circ} \mathrm{C}$. 
Ethics

The study was carried out in accordance with the Declaration of Helsinki of the World Medical Association and was approved by the Committee of Medical Ethics at the General University Hospital in Prague. Informed consent was obtained from the mothers prior to delivery.

\section{mtDNA quantification}

To quantify the mtDNA content, we selected two genes, namely, 16S rRNA gene as a mitochondrial target and GAPDH gene as a nuclear target oligonucleotide sequence $\left(5^{\prime}-3^{\prime}\right)$ : GAPDH forward TTCAACAGCGACACCCACT, reverse CCAGCCACT ACCAGGAAAT and 16S rRNA forward CCAAACCCACTCCACCTTAC, reverse TCATCTTTC CCTTGCGGTA; nucleotide position of amplicons: GAPDH 5270 - 5364 (GenBank accession number AY340484) and 16S rRNA 1683 - 1801 (GenBank accession number J01415). All primers were design using Primer3 program (Rozen and Skaletsky 2000) and synthesized by company Generi Biotech. The nuclear target was used to quantify nuclear DNA (nDNA) and therefore normalization of the mtDNA amount per cell was accomplished. mtDNA content was expressed by the $\mathrm{Ct}$ (mtDNA)/Ct (nDNA) ratio. Threshold cycle $(\mathrm{Ct})$ is the point where the instrument first detects fluorescence above background noise. The fewer cycles it takes to reach a detectable level of fluorescence, the greater the initial template amount. It means that the low $\mathrm{Ct}$ value is detected in sample with the high template concentration and the high $\mathrm{Ct}$ value is detected in sample with the low template concentration. The increasing $\mathrm{Ct}$ value is inversely proportional to the template quantity respectively to the logarithm of the template quantity (Fig. 1). Consequently, in relation to our study, the increasing ratio $\mathrm{Ct}$ (mtDNA)/Ct (nDNA) shows decrease in amount of mtDNA per cell.

Real-time PCR amplification was performed in $25 \mu$ containing $2 \mathrm{X}$ Master Mix DyNAmoTM HS SYBR ${ }^{\circledR}$ Green (Finnzymes), $200 \mathrm{nM}$ each primer and $1 \mu \mathrm{l}$ of each analyzed DNA sample. The concentration of each analyzed DNA sample was always $50 \mathrm{ng} / \mu \mathrm{l}$. The thermal cycling conditions were $95{ }^{\circ} \mathrm{C}$ for $15 \mathrm{~min}$, 40 cycles of $95{ }^{\circ} \mathrm{C}$ for $15 \mathrm{~s}$ and $58{ }^{\circ} \mathrm{C}$ for $18 \mathrm{~s}(16 \mathrm{~S}$ rRNA) or $15 \mathrm{~s}$ (GAPDH) and $72{ }^{\circ} \mathrm{C}$ for $30 \mathrm{~s}$. The following steps were $72{ }^{\circ} \mathrm{C}$ for $5 \mathrm{~min}$ the melting curve from $72{ }^{\circ} \mathrm{C}$ to $92{ }^{\circ} \mathrm{C}$ (fluorescence reading every $1{ }^{\circ} \mathrm{C} / 10$ s) and $72{ }^{\circ} \mathrm{C}$ for $10 \mathrm{~min}$. Data were collected using Chromo4 real-time PCR system (Bio-Rad). Ten-fold
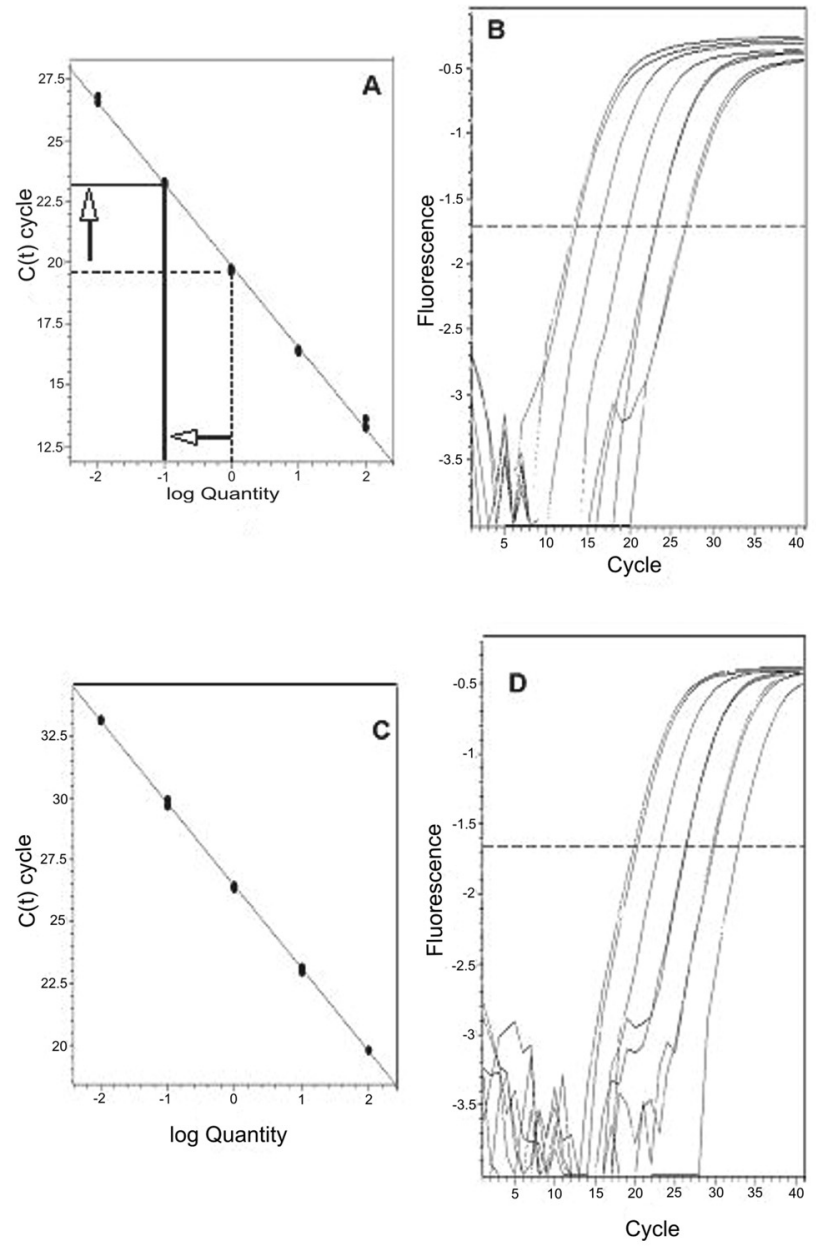

Fig. 1. The calibration curves and their amplification plots. The semilogarithmic plot of mtDNA (mitochondrial DNA) calibration curve $(\mathbf{A})$ represents logarithmic values of DNA input amount in nanograms on $x$ axis and number of cycles to achieve threshold on $y$ axis $\left(y=-3.342 x+19.87, r^{2}=0.999\right)$. The arrows show that the lower is DNA input amount on $x$ axis the higher is number of cycles on $y$ axis and $\mathrm{Ct}$ (cycle threshold) equates to the logaritm of quantity. The mtDNA amplification plot (B) represents the number of cycles on $x$ axis and the fluorescence intensity on $y$ axis $\left(y=-3.343 x+26.43, r^{2}=0.999\right)$, the dashed line shows the threshold line. The calibration curve and the amplification plot for nDNA is shown in (C) and (D).

serial dilutions of the genomic DNA (from $100 \mathrm{ng}$ to $10 \mathrm{pg}$ ) from HCBL were included in each run to generate the calibration curve. The concentration of the DNA was checked spectrophotometrically (Nanodrop Technologies) before each experiment.

Each sample was analyzed in triplet for two times and at least one no-template-control was included with each experiment. A calibration curve was rejected if the correlation coefficient of the trend line was $<0.99$ and the run was repeated. Occasionally, one point from particular triplet was removed if it deviates significantly from the trend line. The slope of the calibration curve 
checked the reaction efficiency.

Each sample was tested for presence of the deleted mtDNA molecules, but none was found positive (data not shown). We used PCR method for the analysis. Amplification of whole mtDNA (LX-PCR) was performed with Takara LA Taq Polymerase and two different sets of primers (Kajander et al. 1999).

\section{Data and statistic analysis}

$\mathrm{Ct}$ (mtDNA) and $\mathrm{Ct}$ (nDNA) were calculated with Opticon 3 Software (Bio-Rad). The threshold was set in the same level for each run. It was up to 10 times the standard deviation above mean baseline emission value. The baseline value was the average fluorescence value of PCR cycles 3-12 (mtDNA) and 3-18 (nDNA).

Pearson's correlation and linear regression analysis were used to evaluate the relationship between mtDNA content and gestational age. The test of correlation coefficient significance was also performed. All statistical analyses were provided by STATISTICA software, version 6.0 (StatSoft, Prague, CZ). Results were considered significant when the corresponding $\mathrm{P}$ value was $<0.05$.

\section{Results}

\section{Designing of the real-time PCR basic parameters}

The method was used to compare the relative abundance of mtDNA with nuclear DNA, using only the $\mathrm{Cts}$ for calculation the ratio mtDNA/nDNA. The $\mathrm{Ct}$ value is inversely proportional to the logarithm of the template concentration (Fig. 1). The $\mathrm{Ct}$ (nDNA) values were used for normalization of $\mathrm{Ct}$ (mtDNA) values. The $\mathrm{Ct}(\mathrm{nDNA})$ values were constant in all real-time PCR runs because the same DNA input was applied for all samples $(50 \mathrm{ng})$. The threshold cycle $(\mathrm{Ct})$ was defined by a certain fluorescence level above mean baseline emission value in cycle range 3-12 (mtDNA) and 3-18 (nDNA). The amount of PCR product was measured at each PCR cycle for the entire PCR process. The correlation coefficient of each calibration curve was between $0.99-1.0$. The efficiencies of reactions were $98 \%$ for both $16 \mathrm{~S}$ rRNA and GAPDH according to the slopes of the calibration curves.

Evaluation of the real-time PCR intra-run and inter-run variability

Intra-run and inter-run assays were performed to assess the precision of the mtDNA and nDNA quantification. The intra-run assay variation was evaluated using three $\mathrm{Ct}$ measurements of 18 different DNA samples. The mean coefficients of variation $(\mathrm{CV})$ were $0.5 \%$ for $\mathrm{Ct}$ of both targets (16S rRNA and GAPDH). The reproducibility between runs (inter-run assay) was assessed from two $\mathrm{Ct}$ measurements in triplicate of 24 different DNA samples and the mean $\mathrm{CV}$ was $0.6 \%$ for $\mathrm{Ct}$ of both targets.

Evaluation of the real-time PCR sensitivity and specificity Sensitivity was determined by the $\mathrm{Ct}$ values that were plotted as a function of the DNA amount (in nanograms) and then the limits of quantification and detection were assessed. The limits of quantification were in range $10 \mathrm{pg}-100 \mathrm{ng}$ of genomic DNA for mtDNA quantification and $100 \mathrm{pg}-100 \mathrm{ng}$ of genomic DNA for GAPDH quantification. $1 \mathrm{pg}$ of genomic DNA for mtDNA quantification and $10 \mathrm{pg}$ of genomic DNA for GAPDH quantification were determined as the limits of detection. Analysis of reaction specificity was provided by melting curve analysis and electrophoresis.

\section{mtDNA quantification}

The significant negative correlation was found between the $\mathrm{Ct}(\mathrm{mtDNA}) / \mathrm{Ct}$ (nDNA) ratio in HCBL and gestational age in the set of 107 neonates born between 25-41 weeks of gestation. It means that $\mathrm{Ct}$ ratio increased but the mtDNA amount per cell decreased during gestation. Using the raw data, correlation analysis gave a Pearson's correlation coefficient of $r=-0.54 \quad(p<0.01)$ (Fig. 2). The correlation analysis only for gestational age 37-41 weeks gave a Pearson's correlation coefficient of $\mathrm{r}=-0.33(\mathrm{y}=0.29+0.0103 \mathrm{x}, \mathrm{p}<0.05)$. There was also a significant negative correlation between $\mathrm{Ct}$ (mtDNA)/ $\mathrm{Ct}$ (nDNA) ratio and birth weight. The Pearson's correlation coefficient was $r=-0.43(p<0.01)$ (Fig. 3). The statistical analysis of individual sample $\mathrm{Ct}$ (mtDNA)/Ct (nDNA) ratios within subgroups was performed to determine outliers and no ones were found.

\section{Discussion}

The detailed data about the physiological changes of mtDNA amount in later fetal development are still scarce. There are studies focused on changes of mtDNA amount during fetal development in both humans and animals, but most of them are concerned with the mtDNA changes in very early fetal development (Vallejo et al. 1996, Garcia et al. 2000, Steuerwald et al. 2000, 

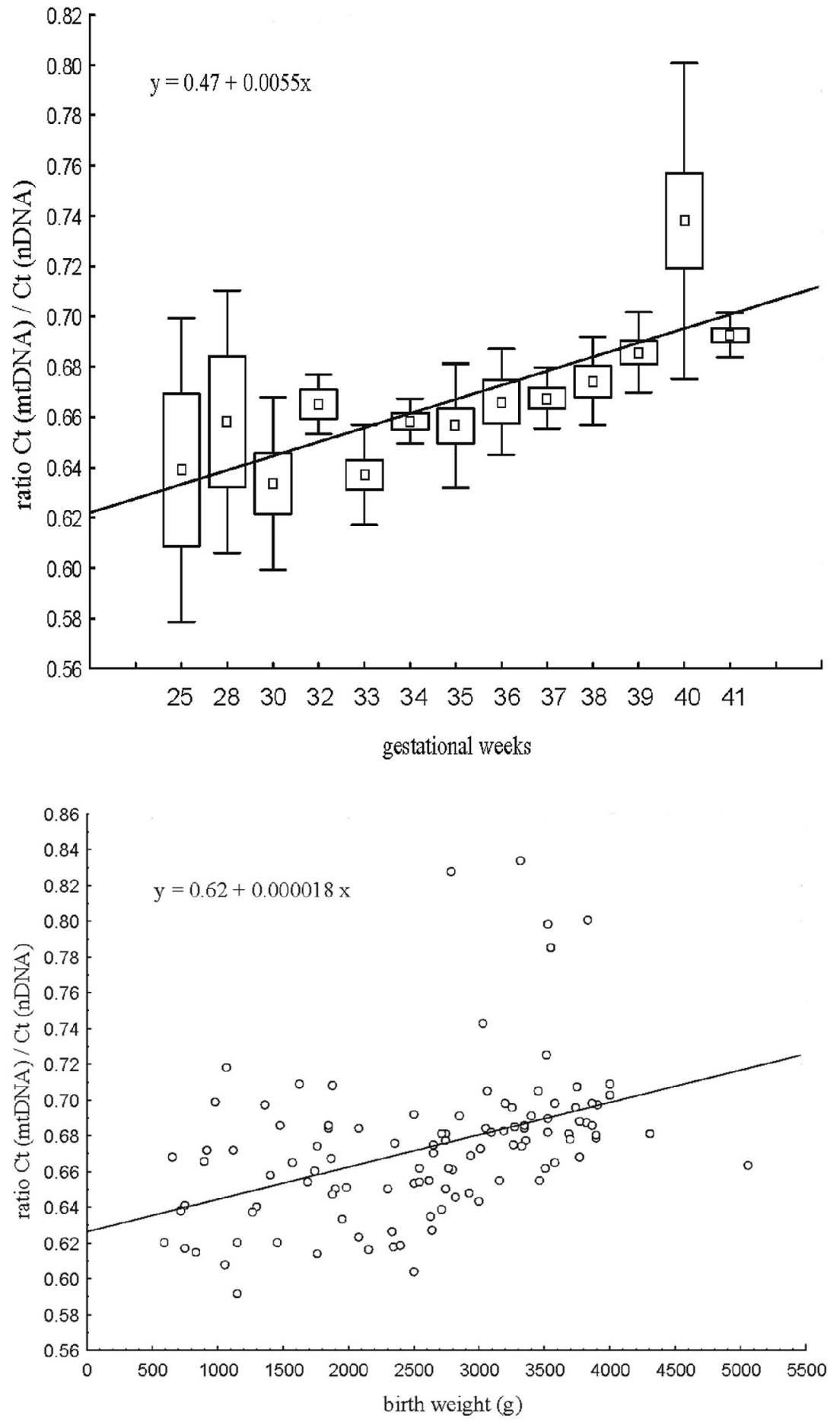

Fig. 2. The correlation between the ratio Ct (mtDNA)/Ct (nDNA) in human cord blood leukocytes and gestational age. There was a significant negative correlation between the $\mathrm{Ct}(\mathrm{mtDNA}) / \mathrm{Ct}$ (nDNA) ratio in human cord blood leukocytes and gestational age during fetal development. It means when the $\mathrm{Ct}$ ratio increased the mtDNA amount per cell decreased during gestation $(\mathrm{n}=$ $107, r=-0.54, p<0.01$ ). The Ct (cycle threshold) value is inversely proportional to the logarithm of the template quantity. It means the lower is the $\mathrm{Ct}$ value the higher is the input amount of template. The $\mathrm{Ct}$ (nDNA) values were used for normalization of $\mathrm{Ct}$ (mtDNA) values. The $\mathrm{Ct}$ ( $\mathrm{nDNA}$ ) values were constant in all real-time PCR runs because the same DNA input was apllied for all samples $(50 \mathrm{ng})$. When the $\mathrm{Ct}$ (mtDNA)/Ct (nDNA) ratio increases the mtDNA amount per cell decreases and vice versa. The ratio represents the relative expression of mtDNA amount per cell. The numbers within the subgroups were $n=3$ in subgroup $25, n=4$ in subgroups 28 and $32, \mathrm{n}=6$ in subgroup $36, \mathrm{n}=7$ in subgroup 34, $\mathrm{n}=8$ in subgroups 30,37 and $38, n=11$ in subgroups $33,40,41$ and $\mathrm{n}=13$ in subgroups 35 and 39 .

Fig. 3. The correlation between the $\mathrm{Ct}$ (mtDNA)/ Ct (nDNA) ratio in human cord blood leukocytes and birth weight. There was a significant negative correlation between the $\mathrm{Ct}$ (mtDNA)/ $\mathrm{Ct}(\mathrm{nDNA})$ ratio and birth weight $(\mathrm{n}=107$, $r=-0.43, p<0.01)$. The Ct value is inversely proportional to the logarithm of the template quantity. It means the lower is the Ct value the higher is the input amount of template. The Ct (nDNA) values were used for normalization of Ct ( $m t D N A$ ) values. The $\mathrm{Ct}(\mathrm{nDNA})$ values were constant in all realtime PCR runs because the same DNA input was applied for all samples (50 \ng). When the $\mathrm{Ct}$ (mtDNA)/Ct (nDNA) ratio increases the mtDNA amount per cell decreases and vice versa. The ratio represents the relative amount of mtDNA per cell.
Reynier et al. 2001, Tamassia et al. 2004, May-Panloup et al. 2005, Alcolea et al. 2006) and only one described the changes in human cord blood leukocytes (HCBL) (Heerdt and Augenlicht 1990). The better knowledge of these changes in later fetal development could elucidate a mechanism of rapid adaptation to respiratory demands of a cell during postnatal switch of glycolytic to oxidative metabolism. The mtDNA level changes are often accompanied by mitochondrial gene expression changes
(Papa 1996). Thus, the increase or the decrease in mitochondrial genomes may reflect a response to respiratory demands of the developing tissues. The imbalance of mtDNA level could have an impact on energy availability in developing tissues and therefore potentially also on secondary postnatal morbidity (Honzík et al. 2007).

Our study is the first fundamental step to gain detailed data about the changes of the mtDNA amount in 
HCBL through fetal development. Results of our study demonstrated the significant changes of mtDNA amount in HCBL during the second part of gestation. The significance of the mtDNA amount changes remained highly significant even if the results of premature neonates were excluded. Therefore the prematurity could not affect the mtDNA content in HCBL.

Surprisingly, we observed that the mtDNA amount in HCBL is decreasing during the gestation contrary to the Heerdt and Augenlicht (1990) who described no significant differences in mtDNA amount between adult and umbilical blood leukocytes and bone marrow. However, in that study, mtDNA amount in leukocytes was analyzed only from two umbilical blood samples and ten peripheral blood samples from adults. Moreover, the adult and fetal samples were compared using Southern blot method. Nevertheless, a significant increase in mtDNA amount was described in liver or kidney during gestation (Heerdt and Augenlicht 1990). We suggest that the trend line of increasing mtDNA amount during development is not a universal marker in all tissues including HCBL. It was similarly demonstrated by Heerdt and Augenlicht (1990).

Several reasons exist why the mtDNA amount could decrease in leukocytes during fetal development. Fetal hematopoiesis moves through several overlapping anatomic and functional stages, beginning in the yolk sac and entering in the hepatic phase at the $6^{\text {th }}$ week of gestation and the marrow phase at the $20^{\text {th }}$ week of gestation. The progression of hematopoiesis in the fetal liver reaches its maximum around the $12^{\text {th }}$ week of gestation and then continuously decreases and simultaneously increases in the bone marrow till birth (Brugnara and Platt 2003). The shift from fetal liver to bone marrow is associated with marked alterations in functional properties of blood cells and the fetal liver continues to produce formed elements of blood into first postnatal week. It means that the blood cells are produced simultaneously from the fetal liver and the bone marrow in the period from $20^{\text {th }}$ week of gestation to the first postnatal week. Transfer to the bone marrow phase is generally complete at birth (Brugnara and Platt 2003, Tavian and Peault 2005). Our study was performed between the sixth and the ninth fetal month when the anatomic shift from the fetal liver to the bone marrow is proceeding (Brugnara and Platt 2003, Baron 2003). Although the number of hematopoietic progenitor cells was proved to be decreasing (Haneline et al. 1996, Wyrsch et al. 1999), this is not a sufficient explanation of decreasing mtDNA amount in HCBL during development. It was verified by excluding the results for premature neonates whose number of hematopoietic progenitor cells is high and quickly falls in contrast to number of hematopoietic progenitor cells in mature neonate blood (Brugnara and Platt 2003). In addition, an upward trend in the number of leukocytes was shown (Forestier et al. 1991). It could be caused by falling of the cell volume during the development as it was observed in erythrocytes (Forestier et al. 1991, Tannirandorn et al. 1999).

Platelets could influence the result of the mtDNA measurement because they contain mtDNA but no nDNA (Banas et al. 2004). However, it was demonstrated that the count of platelets is constant during gestation (Forestier et al. 1991). Therefore our observation of decreasing trend in mtDNA content during gestation is not influenced by possible platelet contamination. The situation in reticulocytes is similar to platelets, the count of reticulocytes is not significantly changing during gestation (Brugnara and Platt 1993). In summary, the growing number of leukocytes as marker of the cell parameter changes together with the overlap of the fetal liver and the bone marrow hematopoiesis could explain the decrease of mtDNA amount per cell in HCBL. Thus, the mtDNA level decrease in HCBL is the secondary effect of the physiological changes in the fetal hematopoiesis.

Although other tissues or cells than HCBL could not be involved in our study, there are several recent studies focused on changes in mtDNA amount in various tissues during aging. Gadaleta et al. (1992) described the increase of mtDNA copy number with aging in liver, heart and brain between adult and senescent rats and Nicklas et al. (2004) showed that the relative mtDNA copy number in rat liver rises at a young age (3-60 days), then decreases and holds fairly steady to 2 years of age. Barrientos et al. (1997a,b) analyzed the changes of mtDNA amount during aging in human brain and skeletal muscle and found out that the mtDNA content increased significantly with age. Garcia et al. (2000) also found an increase of mtDNA content during early human development in heart. On the contrary, Miller et al. (2003) demonstrated no significant change in mtDNA copy number with age in human skeletal muscle and heart. The main reason for these inconsistent human studies is the method used for the mtDNA quantification. Miller et al. (2003) used the real-time PCR method but Barrientos et al. (1997a, 1997b) applied Southern blot 
method and Garcia et al. (2000) performed the mtDNA quantification by the quantitative competitive PCR assay. According to Chabi et al. (2003) and Bhat and Epelboym (2004), the real-time PCR is more accurate and reproducible method for mtDNA quantification than other methods.

In our study, we have decided to use the real-time PCR method because it is the most sensitive and accurate method for mtDNA quantification (Chabi et al. 2003, Bhat and Epelboym 2004). We have established the real-time PCR to compare the relative abundance of mtDNA with nDNA, using only the Cts for the mtDNA/ nDNA ratio calculation. The nDNA amount is directly proportional to the number of cells and therefore the assay result could be expressed as mtDNA amount per cell. The GAPDH was selected as a reference for nDNA. It is an example of a single copy gene that acts as a marker of diploid genome content. Other non-single copy nuclear genes, especially genes for 28S rRNA or 18S rRNA, which have been often used in other studies (Song et al. 2001, Bai et al. 2004, Wong et al. 2004, Cha et al. 2005), seem to be less appropriate. The repetitive nuclear sequences may vary in number and even in primary sequence from one individual to another (Gonzalez et al. 1985); therefore they are not efficient both as an endogenous references and as markers of genome content.

The quantification of mtDNA amount was performed by real-time PCR absolute quantification, but results were expressed relatively using the $\mathrm{Ct}$ (mtDNA)/ $\mathrm{Ct}$ (nDNA) ratio. The absolute expression in number of copies per cell is frequently used and seems to be very helpful. On the other hand, the absolute expression relies on a calibration curve and since there is no way to know exactly how many copies of known template truly exists in a given well of a known sample. Therefore, in our study, the conversion of $\mathrm{Cts}$ to the number of copies per cell was not used because it could affect the accuracy of statistical calculation.

Validation of the real-time PCR parameters, mainly efficiency, was provided by the calibration curve in each run for all experiments. The calibration curve was prepared from the HCBL genomic DNA, because only this genomic DNA has the identical characteristics (primarily efficiencies) as genomic DNA of analyzed samples. Nevertheless, there is possibility to construct DNA plasmid for the calibration curve to quantify mtDNA in absolute number with or without nDNA quantification (Andreasson et al. 2002, Miller et al. 2003, Chabi et al. 2003), but it is necessary to validate the plasmid as model of mtDNA (Pogozelski et al. 2003). Moreover, genomic DNA is a more complex target than plasmid DNA (Brisson et al. 2004).

In conclusion, the real-time PCR method was introduced for quantification of mtDNA and nDNA content in HCBL. Our approach to the relative DNA quantification in HCBL by real-time PCR is sensitive, more accurate, and simpler than other methods used so far (Gahan et al. 2001, Cha et al. 2005). Using this method, we have demonstrated the significant negative correlation between mtDNA content in HCBL and gestational age during the second half of gestation. It means that the mtDNA content per cell in HCBL decreases with progressing fetal development at least from the $25^{\text {th }}$ to $41^{\text {st }}$ week of gestation. The results of this study are in accordance with the hypothesis that in various human developing tissues the mtDNA amount could be different not only depending on their energy demand but also on the stage of development (Heerdt and Augenlicht 1990).

\section{Conflict of Interest}

There is no conflict of interest.

\section{Acknowledgements}

This work was supported by grant GAUK 257557/557/07 (M.P.) and institutional research projects Center of Applied Genomics 1M6837805002, IGA MZ NR/9410-3 (J.Z.) and GACR 303/03/H065 (M.M.).

\section{References}

ALCOLEA MP, COLOM B, LLADO I, GIANOTTI M, GARCIA-PALMER FJ: Mitochondrial transcription factor A (TFAM) is increased in rat embryo during placentation and associated with mitochondrial differentiation. Physiol Biochem 17: 79-88, 2006.

ALONSO A, MARTIN P, ALBARRAN C, GARCIA P, GARCIA O, DE SIMON LF, GARCIA-HIRSCHFELD J, SANCHO M, DE LA RUA C, FERNANDEZ-PIQUERAS J: Real-time PCR designs to estimate nuclear and mitochondrial DNA copy number in forensic and ancient DNA studies. Forensic Sci Int 139: 141-149, 2004. 
ANDREASSON H, GYLLENSTEN U, ALLEN M: Real-time DNA quantification of nuclear and mitochondrial DNA in forensic analysis. BioTechniques 33: 402-411, 2002.

BAI RK, PERNG CHL, HSU CHH, WONG LJC: Quantitative PCR analysis of mitochondrial DNA content in patients with mitochondrial disease. Ann N Y Acad Sci 1011: 304-309, 2004.

BANAS B, KOST BP, GOEBEL FD: Platelets, a typical source of error in real-time PCR quantification of mitochondrial DNA content in human peripheral blood cells. Eur J Med Res 9: 371-377, 2004.

BARON MH: Embryonic origins of mammalian hematopoiesis. Exp Hematol 31: 1160-1169, 2003.

BARRIENTOS A, CASADEMONT J, CARDELLACH F, ARDITE E, ESTIVILL X, URBANO-MARQUEZ A, FERNANDEZ-CHECA JC, NUNES V: Qualitative and quantitative changes in skeletal muscle mtDNA and expression of mitochondrial-encoded genes in the human aging process. Biochem Mol Med 62: 165-171, 1997a.

BARRIENTOS A, CASADEMONT J, CARDELLACH F, ESTIVILL X, URBANO-MARQUEZ A, NUNES V: Reduced steady-state levels of mitochondrial RNA and increased mitochondrial DNA amount in human brain with aging. Mol Brain Res 52: 284-289, 1997 b.

BHAT HK, EPELBOYM I: Quantitative analysis of total mitochondrial DNA: competitive polymerase chain reaction versus real-time polymerase reaction. J Biochem Mol Tox 18: 180-186, 2004.

BRISSON M, HALL S, HAMBY RK, PARK R, SRERE HK: Optimization of single and multiplex real-time PCR. In: A-Z of Quantitative PCR. BUSTIN SA (ed), IUL Biotechnology Series, La Jolla, 2004, pp 621-642.

BRUGNARA C, PLATT OS: The neonatal erythrocyte and its disorders. In: Hematology of Infancy and Childhood. NATHAN DG, ORKIN SK, LOOK AT, GINSBURG D (eds), Saunders, Philadelphia, 2003, pp 19-26.

CHA KY, LEE SH, CHUNG HM, BAEK KH, CHO SW, KWACK KB: Quantification of mitochondrial DNA using real-time polymerase chain reaction in patients with premature ovarian failure. Fert Steril 84: 1712-1718, 2005.

CHABI B, MOUSSON DE CAMARET B, DUBORJAL H, ISSARTEL JP, STEPIEN G: Quantification of mitochondrial DNA deletion, depletion, and overreplication: application to diagnosis. Clin Chem 49: 13091317, 2003.

FORESTIER F, DAFFOS F, CATHERINE N, RENARD M, ANDREUX JP: Developmental hematopoiesis in normal human fetal blood. Blood 77: 2360-2363, 1991.

GADALETA MN, RAINALDI G, LEZZA AMS, MILELLA F, FRACASSO F, CANTATORE P: Mitochondrial DNA copy number and mitochondrial DNA deletion in adult and senescent rats. Mut Res 275: 181-193, 1992.

GAHAN ME, MILLER F, LEWIN SR, CHERRY CL, HOY JF, MIJCH A, ROSENFELDT F, WESSELINGH SL: Quantification of mitochondrial DNA in peripheral blood mononuclear cells and subcutaneous fat using realtime polymerase chain reaction. J Clin Virol 22: 241-247, 2001.

GARCIA J, ANANTHAKRISHNAN R, GOLDENTHAL MJ: Heart mitochondrial DNA and enzyme changes during early human development. Mol Cell Biochem 210: 47-52, 2000.

GONZALEZ IL, GORSKI JL, CAMPEN TJ, DORNEY DJ, ERICKSON JM, SYLVESTER JE, SCHMICKEL RD: Variation among human 28S ribosomal RNA genes. Proc Natl Acad Sci USA 82: 7666-7670, 1985.

HANELINE LS, MARSHALL KP, CLAPP DW: The highest concentration of primitive hematopoietic cells in cord blood is found in extremely premature infants. Pediatr Res 39:820-825, 1996.

HEERDT BG, AUGENLICHT LH: Changes in the number of mitochondrial genomes during human development. Exp Cell Res 186: 54-59, 1990.

HONZIK T, WENCHICH L, BÖHM M, HANSIKOVA H, PEJZNOCHOVA M, ZAPADLO M, PLAVKA R, ZEMAN $\mathrm{J}$ : Activities of respiratory chain complexes and pyruvate dehydrogenase in isolated muscle mitochondria in premature neonates. Early Hum Dev 84: 269-276, 2008.

KAJANDER OA, KUNNAS TA: Long-extension PCR to detect deleted mitochondrial DNA molecules is compromised by technical artifacts. Biochem Biophys Res Commun 254: 507-514, 1999.

KENDALL TL, BYERLEY DJ, DEAN R: Isolation of DNA from blood. Anal Biochem 195: 74-76, 1991.

MAY-PANLOUP P, VIGNON X, CHRETIEN MF, HEYMAN Y, TAMASSIA M, MALTHIERY Y, REYNIER P: Increase of mitochondrial DNA content and transcripts in early bovine embryogenesis associated with upregulation of mtTFA and NRF1 transcription factors. Reprod Biol Endocrinol 3: 65-73, 2005. 
MILLER FJ, ROSENFELDT FL, ZHANG CH, LINNANE AW, NAGLEY P: Precise determination of mitochondrial DNA copy number in human skeletal and cardiac muscle by a PCR-based assay: lack of change of copy number with age. Nucleic Acids Res 31: e61, 2003.

NICKLAS JA, BROOKS EM, HUNTER TC, SINGLE R, BRANDA RF: Development of a quantitative PCR (TaqMan) assay for relative mitochondrial DNA copy number and the common mitochondrial DNA deletion in rat. Env Mol Mut 44: 313-320, 2004.

PAPA S: Mitochondrial oxidative phosphorylation changes in the life span molecular aspects and physiopathological implications. Biochim Biophys Acta 1276: 87-105, 1996.

POGOZELSKI WK, HAMEL CHJC, WOELLER CF, JACKSON WE, ZULLO SJ, FISCHEL-GHODSIAN N, BLAKELY WF: Quantification of total mitochondrial DNA and the 4977-bp common deletion in Pearson's syndrome lymphoblasts using a fluorogenic 5 '-nuclease $\left(\right.$ TaqMan $^{\mathrm{TM}}$ ) real-time polymerase chain reaction assay and plasmid external standards calibrations. Mitochondrion 2: 415-427, 2003.

REYNIER P, MAY-PANLOUP P, CHRÉTIEN MF, MORGAN CJ, JEAN M, SAVAGNER F, BARRIERE P, MALTHIERY Y: Mitochondrial DNA content affects the fertilizability of human oocytes. Mol Hum Reprod 7: 425-429, 2001.

ROZEN S, SKALETSKY H: Primer3 on the WWW for general users and for biologist programmers. In: Bioinformatics Methods and Protocols: Methods in Molecular Biology. KRAWETZ S, MISENER S, (eds), Humana, Totowa, 2000, pp 365-386.

SONG J, OH JY, SUNG YA, PAK YK, PARK KS, LEE HK: Peripheral blood mitochondrial DNA content is related to insulin sensitivity in offspring of type 2 diabetic patiens. Diabetes Care 24: 865-869, 2001.

STEUERWALD N, BARRITT JA, ADLER R, MALTER H, SCHIMMEL T, COHEN J, BRENNER CA: Quantification of mtDNA in single oocytes, polar bodies and subcellular components by real-time rapid cycle fluorescence monitored PCR. Zygote 9: 209-215, 2000.

TAMASSIA M, NUTTINCK F, MAY-PANLOUP P, REYNIER P, HEYMAN Y, CHARPIGNY G, STOJKOVIC M, HIENDLEDER S, RENARD JP, CHASTANT-MAILLARD S: In vitro embryo production efficiency in cattle and its association with oocyte adenosine triphosphate content, quantity of mitochondrial DNA, and mitochondrial DNA haplogroup. Biol Reprod 71: 697-704, 2004.

TANNIRANDORN Y, UERPAIROJKIT B, MANOTAYA S, TANAWATTANACHAROEN S, DANTHAMRONGKUL V, CHAROENVIDHYA D: Fetal hematology. J Med Assoc Thai 82: 598-603, 1999.

TAVIAN M, PÉAULT B: Embryonic development of the human hematopoietic system. Int J Dev Biol 49: 243-250, 2005.

TIMMERMANS EC, TEBAS P, RUITER JPN, WANDERS RJA, DE RONDE A, DE BAAR MP: Real-time nucleic acid sequence-based amplification assay to quantify changes in mitochondrial DNA concentrations in cell cultures and blood cells from HIV-infected patients receiving antiviral therapy. Clin Chem 52: 979-987, 2006.

VALLEJO CG, LOPEZ M, OCHOA P, MANZANARES M, GARESSE R: Mitochondrial differentiation during early development of the brine shrimp Artemia franciscana. Biochem J 314: 505-510, 1996.

VON WURMB-SCHWARK N, HIGUCHI R, FENECH AP, ELFSTROEM C, MEISSNER C, OEHMICHEN M, CORTOPASSI GA: Quantification of human mitochondrial DNA in a real time PCR. Forensic Sci Int 126: 3439, 2002.

WONG LJC: Comprehensive molecular diagnosis of mitochondrial disorders. Ann N Y Acad Sci 1011: 246-258, 2004.

WYRSCH A, CARBONARE VD, JANSEN W, CHKLOVSKAIA E, NISSEN C, SURBEK D, HOLZGREVE W, TICHELLI A, WODNAR-FILIPOWICZ A: Umbilical cord blood from preterm human fetuses is rich in committed and primitive hematopoietic progenitors with high proliferative and self-renewal capacity. Exp Hematol 27: 1338-1345 1999. 